\title{
Occupational hearing loss in teachers: a probable diagnosis.
}

\author{
Regina Helena Garcia Martins ', Elaine Lara \\ Mendes Tavares ${ }^{2}$, Arlindo C. Lima Neto ${ }^{3}$, Marisa \\ P. Fioravanti ${ }^{4}$
}

Keywords: hearing loss, teacher, noise.

\section{Summary}

\begin{abstract}
$\mathrm{T}$
1 eachers frequently report auditory symptoms and excessive noise in classrooms, but noise level measurements are not done routinely. Study model - a prospective clinical trial. Aim - To study auditory symptoms and audiometric exams of teachers and classroom noise levels. Material and Method: Data from two groups, GI (40 teachers) and GII (40 voluntaries) were studied as follows: age, gender, working conditions, audiometric exams, and classroom noise levels. Results - In GI there were more females (86\%), working in basic teaching (75\%), in classes with 21-40 students (70\%), with workloads between 26 and 40 hours per week (47\%), and variable professional teaching time. Most teachers in GI reported excessive classroom noise (93.5\%) and auditory symptoms (65\%). In GI, $25 \%$ of teachers presented audiometric alterations (versus 10\% of controls), with an acoustic notch predominating $(11.25 \%$; $\mathrm{p}<0.05)$. Noise levels close to $87 \mathrm{dBA}$ were recorded in classes at all teaching levels. Conclusions - occupational hearing loss may occur in teachers. Further studies are needed to confirm this proposition.
\end{abstract}

\footnotetext{
${ }^{1}$ Assistant Professor, Doctor on Surgery at the Botucatu Medical School - Unesp. Head of the phoniatrics and voice outpatient unit. Teacher of Otorhinolaryngology at the Paulista State University - Unesp, Botucatu campus.

${ }^{2}$ Master`s degree at the Botucatu Medical School. Speech therapist.

${ }^{3}$ Resident in the Otorhinolaryngology department, Unesp, Botucatu.

${ }^{4}$ Post-graduate student at the Botucatu Medical School - Unesp. Speech therapist in the Otorhinolaryngology discipline of the Botucatu Medical School - Unesp. Júlio de Mesquita Filho Paulista State University - Unesp, Botucatu campus.

Address for correspondence: Regina Helena Garcia Martins - Disciplina de Otorrinolaringologia, Departamento de Oftalmologia, Otorrinolaringologia e Cirurgia de Cabeça e Pescoço da Faculdade de Medicina de Botucatu, Distrito de Rubiao Junior, Botucatu (SP). 18618-970. Telephone/Fax: (0xx14) 3811-6256 - E-mail: rmartins@fmb.unesp.br

aper submitted to the ABORL-CCF SGP (Management Publications System) on March 17th, 2006 and accepted for publication on May 15 th, 2006. cod. 1788.
} 


\section{INTRODUCTION}

Noise-induced occupational hearing loss has been a long-time concern of health professionals. Research on this condition has focused mostly factory and manufacturing workers. ${ }^{1-4}$ Less attention, however, has been given to teachers exposed to classroom noise. It is known that excessive noise in classrooms with many pupils not only hinders learning, but may also lead to psychological harm and organic damage in teachers. These professionals frequently complain of hearing loss, vestibular conditions, tinnitus, and extra-auditory symptoms such as irritability, sleeping difficulties, digestive problems, behavioral disorders, concentration difficulties, and others. ${ }^{5-7}$

An investigation of noise-induced hearing loss in teachers would require confirmation of excessive noise levels in work environments by measuring classroom noise during classes. Pereira et al. ${ }^{8}$ did these measurements in classes where 12 elementary school teachers in a single public school worked; they found a maximum noise peak of $86 \mathrm{dBA}$ and a minimum noise peak of 52dBA.

The audiometric configuration of noise-induced hearing loss shows symmetrical, mild to moderate sensorineural hearing loss mostly at 3,000 and 4,000 Hz. ${ }^{9-11}$ Audiometry should be done upon admission (the initial reference test) to define occupational hearing loss in professionals exposed to noise, and repeated after 6 months and annually. The initial audiometric test is compared to subsequent tests to investigate hearing loss, defined as a $10 \mathrm{~Hz}$ or more difference in auditory thresholds at 3,000, 4,000, and $6,000 \mathrm{~Hz}$ or worsening of $15 \mathrm{~Hz}$ or more in at least one of these frequencies. ${ }^{9-11}$

Most authors believe that an individual may develop noise-induced hearing loss if exposed to constant or intermittent noise at $85 \mathrm{~dB}$ during at least eight hours of work a day.9-11 Many teachers work longer hours in classrooms, including night classes. Routine classroom noise measurements are not done routinely, and there are few papers showing the results of the measurements that are done. It is, therefore, impossible to establish with any precision the true causes of hearing loss in teachers. The situation is different among industry workers, where environmental noise is periodically measured, and where workers are required to use protection equipment.

These comments show the need for evaluating in greater depth the work environment of teachers to identify factors that affect hearing in these professionals.

\section{OBJECTIVES}

Participants in this study included public and private school teachers and aimed to:

-identify auditory symptoms;

- assess auditory acuity;

-verify classroom noise levels;

- correlate audiometric test results to noise exposure;

- compare audiometric test results of teachers and of a volunteer control group.

\section{SERIES AND METHOD}

\section{Series}

The study was approved by the Botucatu Medical School Research Ethics Committee for investigation in human beings (Document number 113/2003). All participants signed a free informed consent form. The series included a sample group (GI) that included 80 teachers from 10 public and private schools in the city of (Sao Paulo state). A control group (GII) was also included to facilitate the interpretation of auditory test results. This group was composed of 40 similarly aged non-teacher volunteers to which were applied the same exclusion criteria.

The sample group (GI) included 69 women (86\%) and 11 men (14\%). The control group included $67.5 \%$ women and $32.5 \%$ men. The age range of teachers was 24 to 59 years ( mean $=40.2$ years), concentrating on the 36 to 50 year age group (55\%). The duration of professional activities was uniform throughout the sample group (Figure 1).

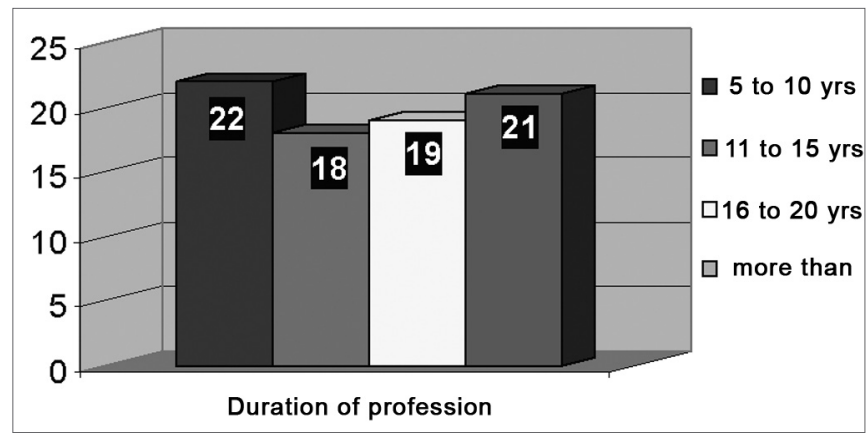

Figure 1. Distribution of teachers according to duration of professional work. 
The weekly workload was as follows: 20 teachers (25\%) worked less than 25 hours, 38 teachers (47.5\%) worked between 26 and 40 hours, and 22 (27.5\%) worked more than 40 hours. There were 60 elementary school teachers (75\%), 13 pre-school teachers (16\%), and 7 junior school teachers (9\%). There were 21 to 40 students per classroom for 56 teachers (70\%); there were fewer than 20 students per classroom for 10 teachers (12.5\%); there were over 40 students per classroom for 14 teachers $(17,5 \%)$.

Exclusion criteria were: a history of otorrhea or otological surgery; congenital or family deafness; auditory pathway malformation; current or past work in another activity where there is/was exposure to excessive noise; use of ototoxic drugs; users of individual sound amplification devices; a history of cranial trauma; altered immitance tests; and work in special subjects (physical education, teaching of religion, teaching foreign languages, etc.). Inclusion criteria were: work as a teacher for over five years; a minimum weekly workload of 20 hours in curricular subjects.

\section{Methodology}

Protocol - teachers initially were interviewed to obtain protocol data on age, gender, auditory symptoms, and working conditions (duration of the profession, number of students per classroom, workload, education level taught, and a description of environmental noise).

Assessment of auditory acuity - teachers in the sample group and control group volunteers initially underwent otoscopy. An assessment of auditory acuity was done with appropriately calibrated devices. Tests included pure tone audiometry (Amplaid® A321 audiometer, Italy) and logoaudiometry (speech audiometry). Audiometric results were classified according to Russo \& Santos (1993);12 normal results were air and bone auditory thresholds between 0 and 25dBNHL. Hearing loss according to audiometry was classified as: flat, sloping, rising, inverted U, and notches (at least a $30 \mathrm{~dB}$ reduction of the audiometric threshold at 4,000 and/or $6,000 \mathrm{~Hz}$ ). When audiometric thresholds were 0 or $5 \mathrm{~dB}$, and if there was a $25 \mathrm{~dB}$ reduction of the audiometric threshold at $4,000 \mathrm{and} /$ or $6,000 \mathrm{~Hz}$ only, the authors classified the audiometric configuration a tending to notches. Speech therapists working as collaborators did the auditory assessments.

Measurement of environmental noise - an ap- propriately calibrated decibelimeter (Larson \& Davis $\AA$ model 812) was used. This device was operated by a single trained technician, who measured classroom noise levels in different teaching levels in three situations: during teacher explanations, during student participation, and during classroom discussions. Minimum and maximum measurements were made, and the energy-equivalent noise level (Leq), which is the average of the sound energy during the measurement period using a $\mathrm{dB}(\mathrm{A})$ frequency filter.

Statistics - data was analyzed using the chisquared method and the comparison of proportions test based on a normal distribution. The significance level was p values equal to or below 0.05 .

\section{RESULTS}

Report of classroom noise $-93.75 \%$ of teachers reported excessive classroom noise.

Auditory symptoms - Table 1 shows that 65\% of teachers had auditory complaints. The most common symptom was hypoacusis (31.25\%), frequently associated with tinnitus and/or vertigo.

Table 1. Prevalence of auditory symptoms in teachers.

\begin{tabular}{lcc}
\hline \multicolumn{1}{c}{ Symptoms } & Teachers & \\
No complaints & $\mathrm{N}$ & $\%$ \\
Hypoacusis & 28 & 35.00 \\
Hypoacusis and & 25 & 31.25 \\
tinnitus & 6 & 7.50 \\
Hypoacusis, tinnitus & 5 & 6.25 \\
and vertigo & & 5.00 \\
Tinnitus & 4 & 2.50 \\
Vertigo & 2 & 1.25 \\
Pain & 1 & 1.25 \\
Fullness & 1 & 2.50 \\
Tinnitus and fullness & 2 & 1.25 \\
Hypoacusis and & 1 & 2.50 \\
pain & 2 & 2.50 \\
Tinnitus and vertigo & 2 & 1.25 \\
Hypoacusis and & & 100.00 \\
vertigo & & \\
Hypoacusis, Tinni- & & \\
tus and pain & &
\end{tabular}




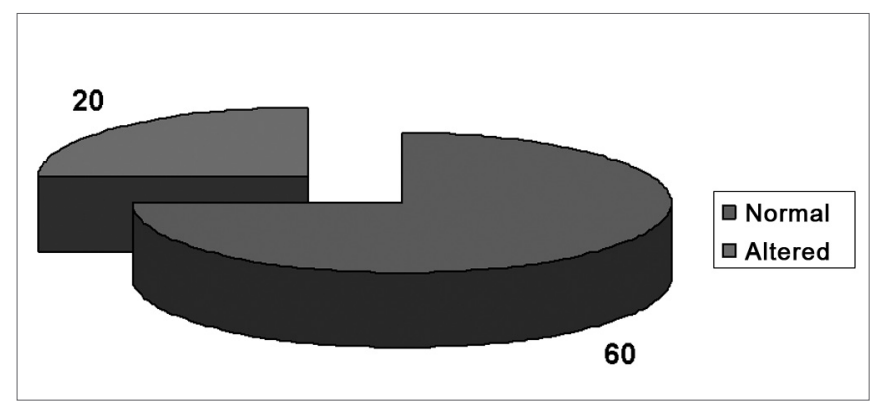

Figure 2. Results of audiometric exams of teachers (Gl).

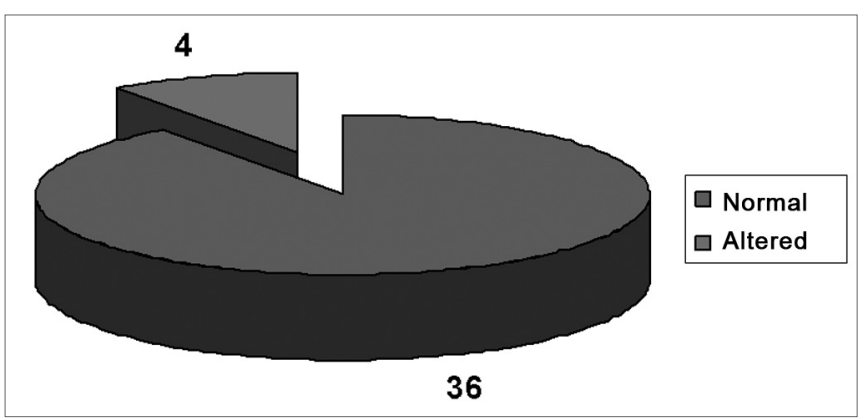

Figure 3. Results of audiometric exams of volunteers (GII).

Table 2. Audiometric tracing configuration of teachers (GI) and of the control group (GII) according to the number of ears tested.

\begin{tabular}{lccccc}
\hline \multirow{2}{*}{ Audiometric tracing } & \multicolumn{2}{c}{ Sample group } & \multicolumn{2}{c}{ Control group } & Value \\
& $\mathrm{N}$ & $\%$ & $\mathrm{~N}$ & $\%$ & dep \\
\hline Normal test & 120 & 75.00 & 72 & 90.00 & $0.003^{*}$ \\
Acoustic drop & 18 & 11.25 & 1 & 1.20 & $0.003^{*}$ \\
Sloping & 13 & 8.10 & 6 & 7.50 & 0.43 \\
Tendency to notches & 3 & 1.87 & 1 & 1.20 & 0.36 \\
Inverted U & 2 & 1.25 & 0 & 0.00 & 0.16 \\
Horizontal & 2 & 1.25 & 0 & 0.00 & 0.16 \\
Rising & 2 & 1.25 & 0 & 0.00 & 0.16 \\
\hline Total & 160 & 100 & 80 & 100 & \\
\hline
\end{tabular}

Table 3. Minimum and maximum values and the Leq of classroom noise level verification in different teaching levels (in dBA).

\begin{tabular}{lcccc}
\hline \multicolumn{1}{c}{$\begin{array}{c}\text { Noise level } \\
(\mathrm{dBA})^{*}\end{array}$} & \multicolumn{2}{c}{ Leq $\mathrm{B}(\mathrm{A})$} & \multicolumn{2}{c}{ Leq dB $(\mathrm{A})$} \\
\hline School level & Minimum & Maximum & Minimum & Maximum \\
Basic School & 63.7 & 87.4 & 73.5 & 82.5 \\
$\begin{array}{l}\text { Elementary } \\
\text { School }\end{array}$ & 59.8 & 87.4 & 69.6 & 84.2 \\
Middle School & 66.9 & 89.0 & 74.6 & 86.4 \\
\hline
\end{tabular}

Results of audiometric tests - audiometric tests (Figures 2 and 3) and audiometric curve configurations (Table 2) revealed that 20 teachers in the sample group (40 ears, 25\%) and only four volunteers in the control group (8 ears, 10\%) had some degree of hearing loss. Notches were the most frequent audiometric configuration, found in 18 ears of teachers in GI (11.25\%) and in one ear of control group volunteers $(1.20 \% ; \mathrm{p}<0.05)$. The sloping audiometric curve was also frequent (GI-8.10\% and GII-7.50\%; p>0.05), followed by a tendency to notches (GI-1.87\% and GII-1.20\%; p>0.05).

All of the participants had a type A normal tympanometric curve.

Classroom noise level - maximum and minimum classroom sound pressure level verification values and the Leq are shown on Table 3; significant environmental noise was found at all teaching levels, at around $87.4 \mathrm{~dB}(\mathrm{~A})$, reaching $89 \mathrm{~dB}(\mathrm{~A})$ in junior school.

\section{DISCUSSION}

This study shows that there were more female teachers in the sample group. Many of them had classrooms with many students and worked over 40 hours a week. This workload probably reflects low wages and the need to supplement the family income, as some authors have pointed out. ${ }^{13-14}$

The working environment of teachers should receive more attention, given the time they remain in classrooms. Crowded classrooms generate significant noise and place excessive demands on phonation. In this context noise verification has not been routine or even required. Most of the teachers in this study reported excessive classroom noise. 190 of 240 teachers assessed by Pérez Fernandez \& Preciato López ${ }^{14-15}$ made similar complaints in a specific questionnaire.

Based on our study we believe that teachers exposed to classroom noise may develop occupational hearing loss throughout their career, given the significant number of auditory symptoms, frequent reports of excessive classroom noise, a large number of altered audiometries compared to the control group ( $40 \mathrm{x} 18$ ), and high classroom sound pressure values in teachers belonging to the GI group. Many teachers had notches in their audiometric configuration, reinforcing the abovementioned assumption. This curve is typical of noise-induced hearing loss and

* Leq-equivalent noise level. 
was found in only 1 control group volunteer and in 18 sample group teachers. This diagnosis, however, is based on a reduction of audiometric thresholds when compared to pre-placement exams, which have not been standardized for teachers. Confirmation, therefore, is limited.

Verification of classroom sound pressure levels is not done routinely, but our investigation revealed elevated values, ranging from $59.8 \mathrm{~dB}$ (A) to $89 \mathrm{~dB}$ (A). If the acceptable noise level for industry workers is $85 \mathrm{~dB}$, and that studies on acoustics applied to education suggest tolerable classroom sound pressures of 40 to $70 \mathrm{~dB}(\mathrm{~A}), 2,16$ we conclude that teachers are exposed to excessive noise levels, notwithstanding Bovo \& Galceran`s17 findings of classroom noise levels up to only $55 \mathrm{~dB}$.

The regulating rule number 15 of the Ordinance 3.214/78,18 which defines tolerance levels for exposure to noise, refers to continuous and intermittent noise, such as that in classrooms. Jiang ${ }^{19}$ underlines the harmful effects of noise originating outside classrooms, showing an increased prevalence of hypoacusis at high frequencies in physical education teachers.

Various authors in past decades have tried to demonstrate the harmful effects of exposure to excessive noise on auditory pathways. This includes studies of industry machine operators, ${ }^{20,21}$ musicians, ${ }^{22}$ military personnel, ${ }^{23}$ drivers ${ }^{24}$ and other recently investigated classes such as hospital workers ${ }^{25}$ and neonates in ICUs. ${ }^{26}$ These papers have provided the basis for assuring the health promotion rights of various workers. Few of these studies, however, have focused on teachers, who experience inadequate working conditions and frequent auditory symptoms.

\section{CONCLUSION}

The high frequency of auditory symptoms, constant reports of excessive classroom noise, the detection of a significant percentage of altered exams with a predominance of notches, and verification of high environmental noise levels, suggest that occupational hearing loss due to noise exposure is present in teachers. This diagnosis needs to be confirmed through pre-placement and periodic exams and further careful studies similar to this paper.

\section{REFERENCES}

1. Alberti PW. Deficiência auditiva induzida pelo ruído
(PAIR). In: Lopes Filho O, Campos CAH, editor. Tratado de Otorrinolaringologia. São Paulo: Roca; 1994. p.93449.

2. Suter AH. The handbook of hearing and the effects of noise: physiology, psychology and public health. Ear and Hear 1996;17(2):176-7.

3. Couto HA, Santino E. Audiometrias ocupacionais: Guia prático. Belo Horizonte: Ergo editora; 1995. p. 116.

4. Coles RRA, Lutman ME, Buffin JT. Guideliness on the diagnosis of noise-induced hearing loss for medico legal purposes. Clin Otolaryngol Allied Sci 2000; 25(4):26473.

5. Oliveira CG. Fonoaudiologia preventiva em saúde do trabalhador. In: Marchesan IQ, Zorzi JL, Gomes ICD. (editors). Tópicos em fonoaudiologia. $1^{a}$ edição. São Paulo: Lovise; 1996. v.3, p.121-29.

6. Anderson K. The problem of classroom acoustics: the typical classroom soundscape is a barrier to learning. Semin Hear 2004; 25:117-29.

7. Seligman J. Efeitos não auditivos e aspectos psicossociais no indivíduo submetido a ruído intenso. Rev Bras Otorrinolaringol 1993; 59:257-9.

8. Pereira MJ, Santos TMM, Viola IC. Influência do nível de ruído em sala de aula sobre a performance vocal do professor. In: Ferreira LP, Costa HO. (eds.) Voz Ativa - Falando sobre o profissional da voz. $1^{\underline{a}}$ edição. São Paulo: Roca; 2000. p.57-65.

9. American college of occupational medicine noise and hearing conservation committee. Occupational noise - induced hearing loss. J Occup Med 1989;31:996.

10. Brasil - portaria $\mathrm{n}^{\circ} 19$, de 09 de abril de 1998 - diretrizes e parâmetros mínimos para avaliação e acompanhamento da audição em trabalhadores expostos a níveis de pressão sonora elevados. Ministério do trabalho. Secretaria de segurança do trabalho. Diário Oficial da União, Brasília, 22 de abril de 1998.

11. Comitê nacional de ruído e conservação auditiva. Perda induzida pelo ruído relacionada ao trabalho. Acta AWHO 1994; 13:126-7.

12.Russo ICP, Santos TMM. A prática da audiologia clínica. 4a․ Ed S. Paulo: Cortez; 1993. pág. 253.

13.Fuess VLR, Lorenz, MC. Disfonia em professores do ensino municipal: prevalência e fatores de risco. Rev Bras Otorrinolaringol 2003;69(6):807-12.

14.Preciado JA, Garcia Tapia RE, Infante JC. Estudio de la prevalencia de los trastornos de la voz en los profesionales de la enseñanza. Factores que intervienen en su aparición o en su mantenimiento. Acta Otorrinolaringol Esp 1998;49(2):137-42.

15.Pérez Fernandez CA. \& Preciado López J. Nódulos de cuerdas vocales. Factores de riesgo en los docentes. Estudo de casos y controles. Acta Otorrinolaringol Esp 2003;54:253-60.

16.Brasil - Associação Brasileira de Normas Técnicas, ABNT; norma NBR 10152. Níveis de ruído para conforto acústico (nb95). 1990.

17.Bovo R, Galceran M. Le disfonie disfunzionali como patologia professionale. In: Fórum Europeo de Ciência, Seguridad y Salud 3. 1998, Oviedo. Ponencia. Oviedo, 1998.

18. Brasil Norma Regulamentadora de $\mathrm{n}^{\mathrm{O}} 15$ (NR-15) da Portaria 3.214/78 do Ministério do Trabalho e Emprego - Secretaria de Segurança e Saúde no Trabalho - Atividades e Operações Insalubres - Diário Oficial da União, Brasília, 08 de junho de 1978. 
19.Jiang T. Risks of noise-induced hearing loss for physical education teachers. J Occup Environ Med 1997;39(10):925-6.

20.Prince MM, Gilbert SJ, Smith RJ, Stayner LT. Evaluation of the risk of noise-induced hearing loss among unscreened male industrial workers. J Acoust Soc Am 2003;113(2):871-80.

21. Harger MR, Barbosa-Branco A. Effects on hearing due to the occupational noise exposure of marble industry workers in the Federal District, Brazil. Rev Assoc Med Bras 2004;50(4):396-9.

22.Juman S, Karmody CS, Simeon D. Hearing loss in steelband musicians. Otolaryngol Head Neck Surg 2004;131(4):461-5.
23.Sewell RK, Song C, Bauman NM, Smith RJ, Blanck P. Hearing loss in union army veterans from 1862 to 1920. Laryngoscope 2004;114(12):2147-53.

24. Correa Filho HR, Costa LS, Hoehne EL, Perez MA, Nascimento LC, de Moura EC. Noise-induced hearing loss and high blood pressure among city bus drivers. Rev Saude Pública 2002;36(6):693-701.

25.Giovinetto R, Roletti S, Saporiti F. The percentage of the population exposed to harmful acoustic pollution levels resulting from vehicular traffic in the hospital area of turin. Radiat Prot Dosimetry 2004;111(4):385-9.

26.Kent WD, Tan AK, Clarke MC, Bardell T. Excessive noise levels in the neonatal ICU: potential effects on auditory system development. J Otolaryngol 2002;31(6):35560. 